\title{
The First Fossil Owl (Aves, Strigiformes) From the Paleogene of Africa
}

\author{
N. Adam Smith ${ }^{1, *(\mathbb{D}}$, Thomas A. Stidham ${ }^{2,3,4}$ and Jonathan S. Mitchell ${ }^{5}$ \\ Campbell Geology Museum, Clemson University, Clemson, SC 29634, USA \\ 2 Key Laboratory of Vertebrate Evolution and Human Origins, Institute of Vertebrate Paleontology and \\ Paleoanthropology, Chinese Academy of Sciences, Beijing 100044, China; presbyornis@gmail.com \\ 3 CAS-Center for Excellence in Life and Paleoenvironment, Beijing 100044, China \\ 4 University of Chinese Academy of Sciences, Beijing 100049, China \\ 5 West Virginia University Institute of Technology, Beckley, WV 25801, USA; jonsmitch2@gmail.com \\ * Correspondence: smith23@clemson.edu
}

Received: 10 April 2020; Accepted: 21 April 2020; Published: 23 April 2020

\begin{abstract}
The relatively extensive fossil record of owls (Aves, Strigiformes) in North America and Europe stands in stark contrast to the paucity of fossil strigiformes from Africa. The first occurrence of a fossil owl from the Paleogene of Africa extends the fossil record of this clade on that continent by as much as $\mathbf{2 5}$ million years, and confirms the presence of large-sized owls in Oligocene continental faunas. The new fossil is tentatively referred to the Selenornithinae, a clade of large owls previously restricted to Europe. This new fossil owl was likely similar in size to the extant Eagle Owls of the genus $B u b o$, and suggests that the niche of large, volant, terrestrial avian predator, although relatively rare throughout avian evolutionary history, may be an ecological role that was more common among extinct owls than previously recognized.
\end{abstract}

Keywords: Egypt; Fayum Depression; Jebel Qatrani Formation; Oligocene; Selenornithinae

\section{Introduction}

Owls (Strigiformes) are a morphologically distinctive, geographically widespread, and relatively diverse clade with a fossil record stretching back more than fifty-five million years [1-3]. Owls are terrestrial predators that occupy higher trophic categories and comprise $>200$ extant species around the globe, being absent today only in Antarctica and a few isolated islands [1]. The fossil record of owls is quite rich overall, including approximately 100 known extinct species with material representing the extant sister clades Strigidae (typical owls) and Tytonidae (barn owls), alongside material referred to several extinct groups of uncertain systematic affinities (i.e., Palaeoglaucidae, Necrobyinae, Selenornithinae, Sophiornithidae, Protostrigidae, and Ogygoptyngidae; reviewed by [2-4]). The relationships of these extinct groups to one another and to the crown clade members of Strigiformes has yet to be evaluated in a rigorous phylogenetic analysis. The absence of such a comprehensive systematic study of the group likely derives from the nature of the owl fossil record, with many named extinct species known only from isolated and otherwise fragmentary fossils. The oldest fossils attributed to the Strigiformes date from the late Paleocene of North America (Ogygoptynx) and Europe (Berruornis; reviewed by [3,4]). Owls evolved large body sizes early in their history, as indicated by the comparable size of specimens attributed to the presumably non-crown group owl Berruornis with that of extant Eagle Owls (Bubo spp.; [3]). The relatively high diversity of smaller sized Paleocene and Eocene fossils from North America, Europe, and Asia demonstrate that owls had diversified greatly in body-size during the Paleogene [2-4]. In contrast, pre-Quaternary strigiform fossils from Africa and the Southern Hemisphere are quite rare with a single record from the Miocene 
of Argentina [5] and a small number of strigiform fossils from South Africa [6]. These regionally differing fossil records currently obfuscate the reconstruction of strigiform historical biogeography and the origin of the clade's current cosmopolitan geographic distribution.

The relatively sparse fossil record of African owls is entirely composed of Neogene and Quaternary specimens from the early Pliocene of South Africa, the late Pliocene of Morocco, the early Pleistocene of Tanzania, as well as several records from Pleistocene cave deposits, and Holocene deposits from islands to the east of Madagascar [2,7-14]. Previously, the oldest reported African specimen of Strigiformes was a distal humerus from the early Miocene ( $18 \mathrm{Ma}$ ) of Kenya that was referred to the extant genus Otus [7]. However, the affinities of the Kenyan specimen are in need of reevaluation, as the taxonomic identification of Walker and Dyke [7] was not supported by the description of any strigiform apomorphies present in the fossil and the referral to Otus was subsequently questioned by Pavia et al. [6]. An isolated alar phalanx from the middle Miocene ( 13 Ma) of Morocco was referred to the extant species Tyto alba by Brunet $[15,16]$. Naturally, the potential presence of an extant species in the middle Miocene raises issues related to species longevity (see discussion in $[17,18]$ ), and that particular taxonomic identification also was questioned by Pavia and Mourer-Chauviré [19]. Therefore, the earliest reliable records of African owls are from the richly fossiliferous, early Pliocene ( 5.0 Ma) deposits at Langebaanweg, South Africa $[6,20]$. Thus, the discovery of a new strigiform fossil from the early Oligocene [ $\sim 30 \mathrm{Ma}]$ Jebel Qatrani Formation of Egypt (Figure 1) extends the African strigiform fossil record by approximately 25 million years. We refer to this specimen (and the species it represents) herein as the 'Jebel Owl'.

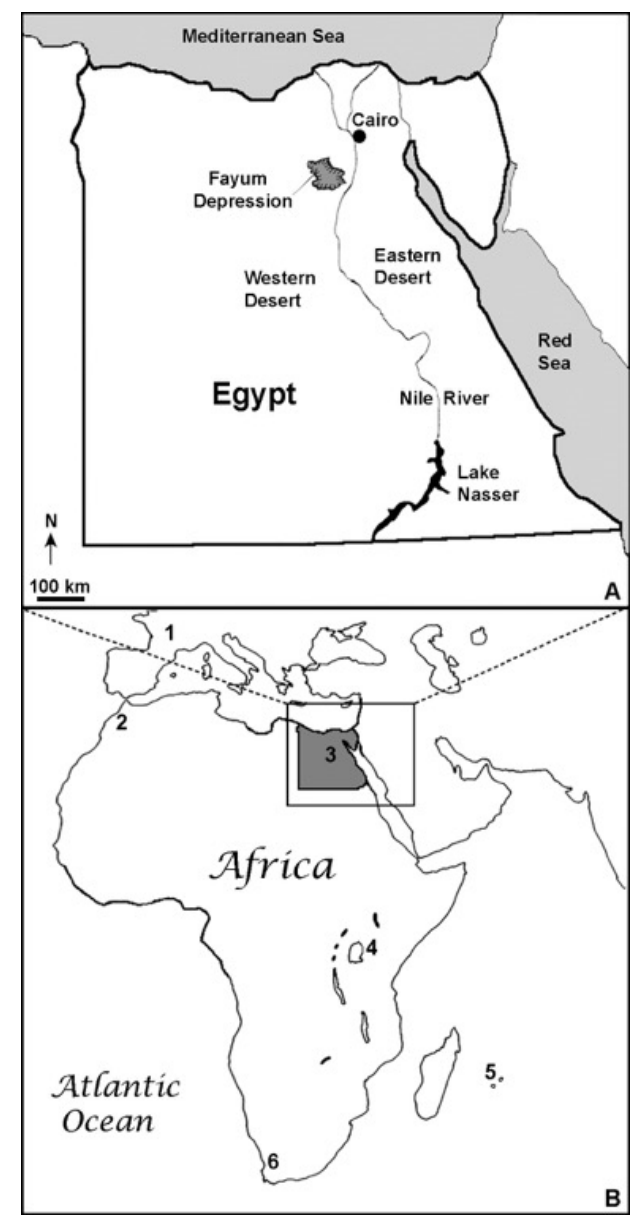

Figure 1. Maps depicting the location of the Fayum Depression fossil locality in Egypt (A), Quercy fissure fill fossil owl locality in France and previous African strigiform fossil localities (B): Quercy, France (1); Ahl al Oughlam Quarry, Casablanca, Morocco (2); Fayum Depression, Egypt (3); Olduvai Gorge, Tanzania (4); Mauritius and Reunion Island (5); Langebaanweg, South Africa (6). 


\section{Materials and Methods}

\subsection{Osteological and Geologic Conventions}

In the osteological description, the English equivalents of the Latin nomenclature, summarized by Baumel and Witmer [21], are used. Osteological measurements of fossil specimens and extant strigiformes follow those outlined by von den Driesch [22], and were taken using digital calipers, rounding measurements to the nearest $0.1 \mathrm{~mm}$ (see Supplementary Data File S1). Ages of geologic time intervals are based on the International Geologic Time Scale [23]. A complete list of extant comparative skeletal material and measurements of those specimens are included in the Supplementary Materials section.

\subsection{Institutional Abbreviations}

CU, Campbell Museum of Natural History, Clemson University, Clemson, South Carolina, USA; DPC, Duke Lemur Center, Division of Fossil Primates, Duke University, Durham, North Carolina, USA; FMNH, Field Museum of Natural History, Chicago, Illinois, USA; MNHN, Muséum National d'Histoire Naturelle, Paris, France; NCSM, North Carolina Museum of Natural Sciences, Raleigh, North Carolina, USA; USNM, Smithsonian Institution, National Museum of Natural History, Division of Birds, Washington, District of Columbia, USA.

\section{Systematic Paleontology}

Aves Linnaeus, 1758 [24]

Strigiformes Wagler, 1830 [25]

cf. Selenornithinae Mourer-Chaviré, 1987 [26]

\subsection{Referred Specimen}

The specimen (DPC 24780; Figure 2) was originally included in a series of unrelated and unassociated fossil remains and was not initially assigned a unique specimen number (original specimen number for entire lot of fossils: DPC 5061, field number 84-27). The specimen is the distal end of a left tibiotarsus that was collected by P.S. Chatrath in 1984 during a joint expedition of Duke University and the Egyptian Geological Museum. Although DPC 24780 likely represents a species of owl that was previously unknown (see taxonomic comparisons below), in the interest of avoiding taxonomic confusion, DPC 24780 is not designated as the holotype specimen of a new species because of the limited amount of preserved morphology. Additional remains from this taxon will be required to allow for the resolution of its systematic position and its formal taxonomic recognition.

Measurements $(\mathrm{mm})$ : preserved proximodistal length of fragment 30.5; mediolateral width across distal condyles 13.6; preserved craniocaudal depth across condyles 14.7; least mediolateral breadth of shaft 9.7 (see Table 1 for comparisons with other taxa).

\subsection{Locality}

DPC 24780 was collected from Quarry I (sensu $[27,28]$ ) of the Jebel Qatrani Formation in the Fayum Depression of northern Egypt (Figure 1). Based on the geochronological data of the various quarries summarized by Seiffert [29], the estimated age of the fossil is 30 Ma (i.e., early Oligocene: Rupelian). The Jebel Qatrani Formation conformably overlies the late Eocene fluviomarine Qasr el Sagha Formation and is composed of a mixed sequence of lithified siliciclastic and carbonaceous sediments. The Jebel Qatrani Formation has been interpreted as the result of primarily fluvial deposition and is characterized by abundant weathering horizons and root traces indicative of a tropical monsoon climate regime (see $[28,30]$ for further geologic and paleoenvironmental details). Fossil records of birds, mammals (particularly primates), and flora are congruent with these geologic and climatic interpretations (reviewed by $[27,29,30]$ ). 


\subsection{Anatomical Description}

The specimen is the distal end of a left tibiotarsus that is broken just proximal to the proximal margin of the extensor groove (Figure 2). The proximal end of the shaft on the caudal side is missing. Additionally, the distal and caudal faces of the distal end (including those faces of the condyles) are missing, including the articulation for the tibial cartilage. The specimen is interpreted as representing an adult individual, indicated by the completely fused astragalus and calcaneum and a smooth cortical surface [31,32]. The fragmentary and abraded preservation of DPC 24780 is consistent with other avian fossils from the Jebel Qatrani Formation and is not an indication of ontogenetic stage.

Table 1. Tibiotarsal measurements of selected extant and large extinct species of owls (mm).

\begin{tabular}{ccccc}
\hline Species & $\boldsymbol{n}$ & $\mathbf{t l}$ & $\mathbf{t s w}$ & tdw \\
\hline Bubo bubo & 3 & 138.0 & 5.3 & 17.5 \\
Bubo scandiaca & 5 & 117.6 & 5.1 & 15.8 \\
Bubo virginianus & 10 & 124.3 & 5.2 & 15.6 \\
Strix nebulosa & 5 & 118.7 & 4.9 & 14.5 \\
Strix occidentalis & 4 & 94.9 & 3.7 & 10.7 \\
Strix otus & 4 & 77.2 & 2.8 & 8.5 \\
Strix varia & 10 & 106.0 & 3.8 & 12.0 \\
Aegolius acadicus & 4 & 46.9 & 1.8 & 5.5 \\
Asio flammeus & 4 & 86.2 & 3.0 & 8.9 \\
Micrathene whitneyi & 3 & 38.3 & 1.8 & 4.0 \\
Otus asio & 9 & 54.1 & 2.2 & 6.5 \\
Tyto alba & 6 & 106.4 & 4.2 & 10.6 \\
tOrnimegalonyx oteroi & 1 & 250.0 & 13.0 & - \\
tTyto gigantea & 1 & 195.0 & 9.7 & - \\
+Tyto noeli & 1 & 147.0 & 6.4 & - \\
tNecrobyas arvernensis & 1 & 77.9 & 4.3 & 10.0 \\
tGrallistrix auceps & 1 & 110.8 & 4.9 & 10.2 \\
tGrallistrix orion & 1 & 101.9 & 4.2 & 9.6 \\
tGrallistrix erdmani & 1 & 96.0 & 4.6 & 9.2 \\
tEostrix mimica & 1 & - & 6.0 & 11.4 \\
tcf Selenornithinae (Jebel Owl) & 1 & - & 9.7 & 13.6 \\
\hline
\end{tabular}

+ denotes extinct species; - denotes missing data; tibiotarsal length (tl) is greatest length excluding the cnemial crests; shaft width (tsw) values are least width in the mediolateral plane; distal width (tdw) values are greatest mediolateral width (see [33]). All measurement values provided for extant species are averages. For a complete list of sampled species, specimens, and osteological measurements, see the supplementary data (Data File S1).

At the proximal preserved end, there is still a slight concavity extending from the extensor sulcus, which widens and deepens distally. The distal end of the extensor sulcus forms a relatively deep excavation with its long axis medial to the proximodistal midpoint of the bone. The most distal end of the sulcus has a very slight overhang cranially (i.e., a small fossa in the distal end of the sulcus). There is no ossified supratendinal bridge, nor any evidence that one was present and later broken away. On the medial side, at approximately one-half the proximodistal length of the specimen, is the medial attachment of the extensor retinaculum. It is ovoid in outline and proximodistally elongate. In contrast, the lateral extensor retinaculum attachment is mediolaterally wide and has an irregular outline. Located medial to that attachment scar is a medial widening of the tibial shaft (relative to the more proximal part of the shaft). The preserved portion of the lateral condyle extends slightly further proximally than the medial condyle. The condyles are subequal in mediolateral width, with the lateral condyle being slightly wider. The proximal end of the medial condyle at the junction with the shaft is more rounded than the somewhat pointed proximal end of the lateral condyle. The preserved part of the medial face of the shaft is relatively flat. The medial condyle is concave cranial to the epicondyle. The medial epicondyle is relatively distinct and located just cranial to the level of the cranial face of the tibial shaft. The proximal end of the medial condyle has a small concave notch in its outline where it meets the shaft. Adjacent to that notch is an oval shaped scar that is elevated relative to the rim of 
the medial condyle (see the pit adjacent to the extensor sulcus on Figure 2). The lateral surface of the lateral condyle is relatively flat with an irregular outline in lateral view. There does not appear to be a lateral epicondyle, but it may have been present on the missing portion of bone. The more proximal area of the lateral side of the bone is convex. The sulcus $\mathrm{m}$. fibularis is less deeply excavated than the notch at the junction of the medial condyle and the shaft. There is a small pit on the lateral side adjacent to that junction. Caudal to that pit is a low ridge and groove, which are relatively short and proximodistally elongate.

A

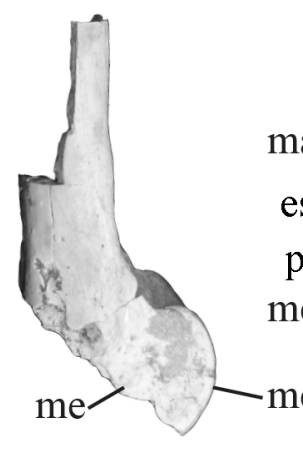

E

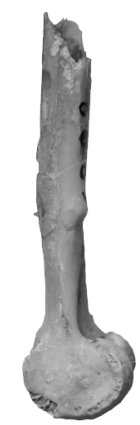

I

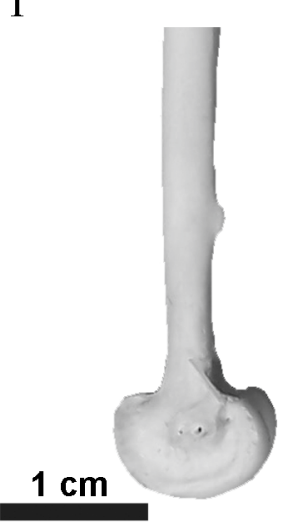

B

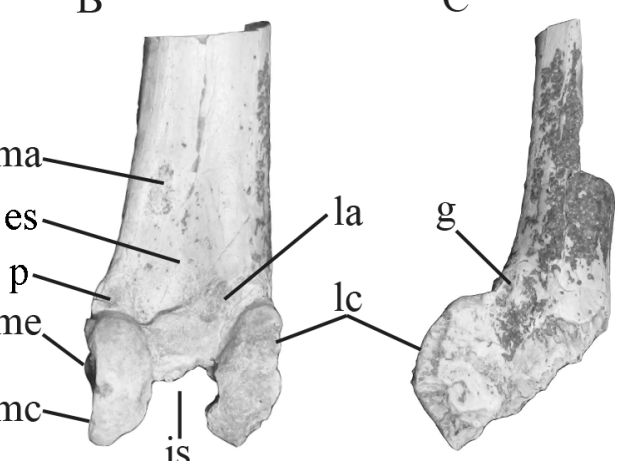

F

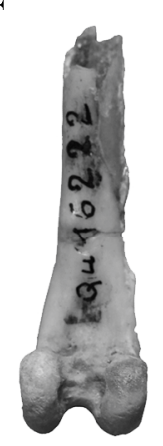

J

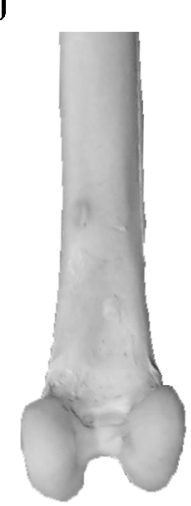

G

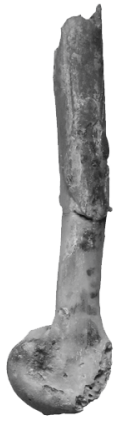

K

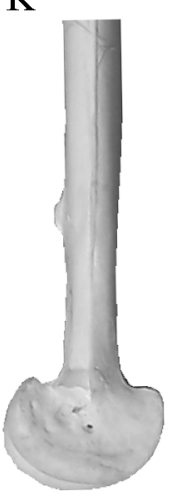

D

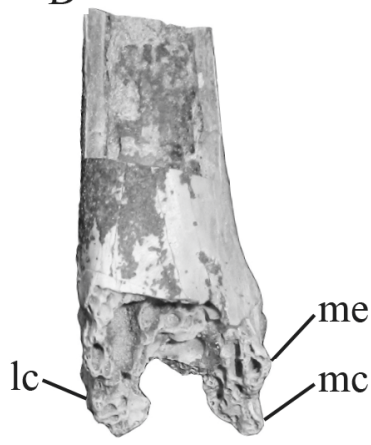

$\mathrm{H}$

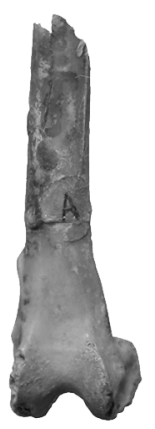

L

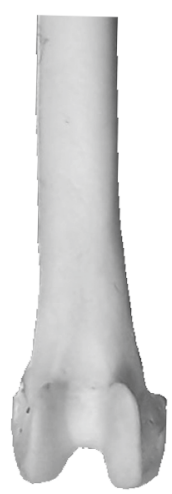

Figure 2. Distal left tibiotarsi of: the Jebel Owl (DPC 24780); the holotype specimen of Selenornis henrici (MNHN QU-16222); and Tyto alba (CU 1827) in medial (A,E,I), cranial (B,F,J), lateral (C,G,K), and caudal $(\mathbf{D}, \mathbf{H}, \mathbf{L})$ views. Anatomical abbreviations: es-extensor sulcus, $\mathrm{g}$ - groove and depression adjacent to lateral condylar notch, is-intercondylar sulcus, la-lateral attachment of the extensor retinaculum, lc-lateral condyle, ma-medial attachment of the extensor retinaculum, mc-medial condyle, me-medial epicondyle, $\mathrm{p}$ - pit adjacent to extensor sulcus. 


\subsection{Taxonomic Comparisons}

Although the specimen (DPC 24780) is only a fragment of a limb bone, major postcranial skeletal elements (e.g., tibiotarsus, tarsometatarsus) of owls are quite distinct from those of other avian clades and are therefore, readily identifiable $[4,33]$. Furthermore, it is fortuitous that such a fragmentary specimen preserves apomorphies that allow for its tentative referral to Selenornithinae. The absence of an ossified supratendinal bridge on the tibiotarsus (Figure 2) is a characteristic with a very limited distribution among (adult) crown group birds. Within crown birds, the supratendinal bridge is not ossified in most 'ratite' paleognaths (likely not a monophyletic group), some Podicipedidae (grebes), some Psittaciformes (parrots), Opisthocomidae (hoatzin), Steatornithidae (oilbirds), Nyctibiidae (potoos), Bucerotidae (hornbills), and Strigiformes (owls; [34]). Ameghinornithidae (Cariamae putatively outside of core Gruiformes sensu [4]) also lack an ossified supratendinal bridge, and a fossil tentatively attributed to this taxon was reported from the Jebel Qatrani Formation in Egypt [35]. Based on the phylogenetic relationships among those groups, it is most parsimonious to reconstruct that absence (in adult individuals) as a convergent feature rather than retention of a plesiomorphy, or as a derived (reversed) character uniting any of those groups (possibly with the exception of some of the ratite paleognaths). The extensor sulcus has a deeply excavated pit on the cranial surface of the distal tibiotarsi in Strigiformes. Whereas, the extensor sulci are not deeply excavated in paleognathous birds lacking a bridge, Opisthocomidae, Podicipedidae, and Steatornithidae. The extensor sulci of Psittaciformes and Bucerotidae are less deeply excavated than in Strigiformes. The medial epicondyle is considerably more projected in Ameghinornithidae than in DPC 24780 (see [35], figure 2). These characters (i.e., lack of an ossified supratendinal bridge and a deeply excavated extensor sulcus) are primary characters indicating support for the referral of DPC 24780 to Strigiformes. In addition, the evenly rounded outline, distinct craniodistally projecting condyles of subequal mediolateral width with a very deep intercondylar incisure (broken, but the preserved distal ends of the condyles indicate a deep incisure) further agree with the allocation of this fossil to Strigiformes.

The specimen does not display the wide medial condyle characteristic of the Paleogene Protostrigidae [4]. The relatively narrow condyles, relatively wide tibiotarsal shaft, and the depression proximal to the lateral condyle of DPC 24780 agree with the morphology of Selenornis (Selenornithinae). These apomorphies of Selenornis were noted previously by Mourer-Chauviré [26] and Mayr [36]. However, it is unclear if DPC 24780 possessed the shallow tibiotarsal cartilage articulation present in Selenornis (mentioned by [36]) because the caudodistal region of the bone is missing. It appears that Selenornis steendorpensis (see [36], figure 2) shares the more distal location of the extensor retinaculum present in DPC 24780, and they differ from the more proximal location observed in Berruornis orbisantiqui and Tyto. That feature has not been described in the Selenornis (Sophiornithidae) material from Quercy. The extensor sulcus of DPC 24780 is relatively deeper than that of S. steendorpensis. The preserved portion of the lateral condyle extends slightly further proximally than the medial condyle; although the difference is very slight, as is that of S. steendorpensis, in which the opposite condition is reported [36]. The tubercular attachment of the medial side of the extensor retinaculum is located just distal to the preserved end of the bone in B. orbisantiqui [13], a position more proximal than that in DPC 24780 (and overall more similar to that in Tyto). Additionally, DPC 24780 also exhibits a flattened scar, not a tubercle for that attachment point adding another difference between these two taxa. The tibiotarsual shaft of DPC 24780 is also significantly more robust than B. orbisantiqui (width of shaft across retinacular tubercles in B. orbisantiqui $=8.6 \mathrm{~mm}$; see [13], table 2; DPC $24780=13.1 \mathrm{~mm}$ ). DPC 24780 is not directly comparable to the Paleocene Ogygoptynx wetmorei (Ogygoptyngidae), which is known only from a tarsometatarsus [37]. However, given that the proximal tarsometatarsus articulates with the distal tibiotarsus, the $9.0 \mathrm{~mm}$ proximal width of $O$. wetmorei suggests that this taxon was considerable smaller than the species represented by DPC 24780. Likewise, the width of proximal tarsometatarsus of Palaeobyas cracrafti ( $16.5 \mathrm{~mm}$, see [26], table 5) suggests that P. cracrafti was somewhat larger than DPC 24780. Based on width of the tibiotarsal shaft, DPC 24780 is significantly larger in size than Necrobyas edwardsi, N. harpax, and N. arvernensis (Necrobyinae; see [26], table 5; Table 1). DPC 24780 
is not comparable to the large owl Palaeotyto cadurcensis reported from the Quercy fissure fillings by Mourer-Chauviré [26] because that taxon is known from an isolated coracoid. The minimum width of the tibiotarsal shaft of DPC $24780(9.7 \mathrm{~mm})$ is the same as that of Tyto gigantea. Based on measurements of the distal tibiotarsus, DPC 24780 was slightly smaller than Tyto robusta and T. mourerchauvirae (see table 2 in [38]). Although the shaft width of DPC 24780 is nearly double that of the largest extant owl Bubo bubo, the distal width and depth of DPC 24780 are somewhat smaller (Table 1), indicating a potentially diagnostic difference in relative proportions between these taxa.

\section{Discussion}

Much like that of the Jebel Qatrani avifauna, other predominantly freshwater aquatic African avifaunas from the Eocene and Miocene of Egypt [27,39,40] and the Miocene of Kenya [41] provide a limited means of comparison with extinct assemblages and extant African avifaunas. For example, fossil Ciconiiformes (storks, herons, and allies) are present in all of the deposits mentioned above and are widespread on the African continent today. Furthermore, compositional evaluation of the avifauna from the Fayum Depression of Egypt showed that the assemblage somewhat resembled that of the extant avifauna of Uganda in eastern Africa [42]. Thus, despite the relative antiquity of the remains described herein (i.e., early Oligocene), and as noted by Olson and Rasmussen [42], the avifaunal composition of the Jebel Qatrani Formation is not entirely dissimilar from modern African deltaic avian assemblages. The addition of an owl to the Jebel Qatrani avifaunal assemblage is entirely consistent with that interpretation.

Based on comparisons of tibiotarsal measurements, Jebel Owl would have likely been within the range of the largest extant owls, the Eagle Owls (Bubo spp.; body mass $~ 1.5-2.5 \mathrm{~kg}$ [43]). Although tibiotarsus measurements indicate differences in relative proportions among large extinct owls (Table 1), the Jebel Owl appears to be similar in size with many of the larger Paleogene owls, such as Minerva and Berruornis [4,13], and the Jebel Owl likely would have been one of the larger avian predators within the northern African deltaic paleoecosystem. The presence of a large owl in the Fayum ecosystem is not wholly unexpected and adds to the known diversity of presumably carnivorous birds during that time (e.g., osprey and a possible accipitrid; [27]). An evaluation of body size evolution in extant and extinct Strigiformes found evidence that there is no overall trend in insular body size evolution despite the increased occurrence of large bodied insular taxa (such as Tyto balearica) in the fossil record as compared to large extant owls, and that no overall trend in insular body size evolution is apparent in the clade [44]. The addition of the Jebel Owl to the list of large strigiformes does not challenge that interpretation. However, given the temporal duration of large owls (i.e., Oligocene-Pleistocene), it is likely that additional strigiformes of unusually large size remain to be discovered.

Fossil remains from the Jebel Qatrani Formation include those of early Oligocene primates, such as Propliopithecus (also known from Quarry I; [45]). Propliopithecus has been estimated as weighing between 3.6 and $7 \mathrm{~kg}[45,46]$ placing juveniles and potentially adults within the pool of prey hunted by an owl as large as Jebel Owl. Extant examples of this foraging specialization include the African Crowned Eagle, in which primates represent the majority ( $80 \%)$ of the diet [47]. Additionally, large raptors are known to produce fossil accumulations with diagnostic characteristics [48]. The possibility that the accumulation of primate remains from the Jebel Qatrani Formation is due to the foraging activities of Jebel Owl or other large carnivorous birds should be considered, given that other primate fossil deposition has been attributed to large raptors (e.g., Australopithecus africanus; [49]). However, taphonomic and depositional interpretations of the Jebel Qatrani Formation suggest that the fossil assemblage was deposited in a deltaic or estuarine setting [28], and further study is necessary to determine if the Jebel Owl could have been a significant contributor to the known primate fossil record in the Fayum. The Jebel Qatrani Formation should be a target of future collection efforts to identify additional remains of this owl and to garner additional insights regarding the ecological interactions of this large extinct owl. 
Most extant owls are nocturnal predators [1], and along with bats, they dominate terrestrial, volant, nocturnal, predatory niches. However, it is not known how and when in their long evolutionary history owls became nocturnal predators and rose to dominance. The phylogenetic relationships of owls to other neoavian birds is unclear, but some genomic analyses $[50,51]$ suggest a relatively close relationship with the herbivorous extant mousebirds, who were frugivourous early in their history [52]. Carnivory likely is an apomorphy of the strigiform lineage given the omnivorous or herbivorous diets of other related landbirds (Telluraves). As with the Jebel Owl, most other Paleogene owl fossils are limited to postcranial elements. Cranial features that could indicate relative eye size and associated nocturnal versus diurnal habits (e.g., lacrimals fused to frontals and supraorbital processes absent or vestigial) are frequently not preserved in owl fossil specimens [3]. However, a privately held early Eocene owl fossil with a well-developed supraorbital process and suggesting that at least one lineage of stem owls may have had smaller eyes and been less nocturnal than modern owls was reported by Mayr [3]. Extant owls are unique in their role as large, avian, aerial, nocturnal predators, and it is tempting to speculate that invasion of this potentially unoccupied niche (along with the similar rise and dispersal of nocturnal mammals including rodents and primates) may explain the wide geographic distribution of the clade early in their evolutionary history.

The potential presence of a selenornithid owl in Africa presents interesting new biogeographic data for the evolution of birds along the Tethys Seaway because with a few exceptions, the bulk of research on dispersal to and from Africa in the Paleogene has focused on mammals and reptiles [53-55]. Despite the much richer record of mammals from the Eocene and Oligocene of Asia, Europe, and Africa, current data does not reveal a consistent biogeographic dispersal pattern among those continents $[55,56]$. However, the presence of related taxa on both sides of Tethys (i.e., in Europe and northern Africa) indicates that dispersal did occur, even though the timing and directionality of those events have not yet been constrained [55]. Indeed, if Jebel Owl is closely related to the known Selenornithinae species from Europe (see comparison section above), its presence in northern Africa would strengthen the trans-Tethyian biogeographic links among birds in the late Eocene and early Oligocene beyond the occurrence of osprey, ameghinornithids, and herons $[4,35,57,58]$. Many of the Eocene and Oligocene birds recently described including ameghinornithids, cuckoos, galliforms, and parrots comprise species without clear affinities to known taxa within their respective systematic groupings, or species within widely occurring groups such as Parortygidae and Ameghinornithidae (present in the Paleogene of Africa, Europe, and Asia; [35,59,60]. This mixture of endemicity (or lack of clear biogeographic affinities) with avian taxa distributed widely in the Old World means that determining the paleobiogeography of Africa, with respect to other regions (Europe and Asia), will require analysis of significant new data and fossils.

The Eocene-Oligocene Climatic Transition (EOCT) lasted from approximately 33-34 Ma, and that particular temporal interval has been correlated with global cooling and significant changes in sea level [61]. Furthermore, molecular divergence estimates and the fossil record suggest that the EOCT was a time of global avian radiation and faunal turnover $[62,63]$. Widespread climatic changes such as those associated with the EOCT may have affected both terrestrial species such as the Jebel Owl and marine taxa such as pelagornithids. However, the dynamics of those interactions between the physical environment and birds living in vastly different habitats likely differed. For example, the early Oligocene age of the Jebel Qatrani fauna is congruent with significant changes in the mammalian fauna of Europe (i.e., the Grande Coupure), and the biotic interchange and subsequent faunal turnover that resulted have been documented in the mammalian fossil record of adjacent areas of Europe and Asia [56]. Likewise, loss of the mammalian megafauna in North and South America has been implicated as a potential contributing factor in the extinction and reduction of giant scavengers, such as the teratorns and condors $[64,65]$. Additionally, new evidence suggests that the Nile River drainage system formed contemporaneously with the estimated age of Jebel Owl ( 30 Ma; [66]) and the subsidence of northern Egypt and changing environment of that time period may have played a role in the creation of the niche occupied by this large owl. However, additional information regarding the geographic 
and temporal distribution of the Jebel Owl will be needed before paleoclimatic and faunal impacts can be assessed with any certainty.

\section{Conclusions}

Whereas many avian giants are known from insular or marine faunas (e.g., moas, elephant birds, Ornimegalonyx, and pelagornithids), the occurrence of the Jebel Owl in Egypt demonstrates that large sized avian predators interacted with continental Oligocene faunas as well, and likely were not restricted to scavenging. Questions regarding how this large flying predator interacted with its physical environment (e.g., flight dynamics), its prey, and other predators remain unresolved. Nevertheless, the discovery of the Jebel Owl further demonstrates that large body size in birds evolved in both terrestrial and marine environments and across different foraging niches.

This new Egyptian fossil represents the first record of an owl from the Paleogene of Africa and extends the fossil record of African owls by as much as 25 million years. Jebel Owl would likely have been similar in size to the extant Eagles Owls and potentially could have preyed upon a large cross section of the vertebrate fauna. As a potential apex predator, the Jebel Owl may have contributed to the structuring of the mammalian community of northern Africa during the Oligocene. In contrast with other avian giants that are frequently herbivorous or restricted to marine or insular habitats, the Jebel Owl demonstrates that volant, avian, terrestrial predators of large size were likely more geographically widespread and may have a more extensive evolutionary history than previously appreciated. The presence of owls in the Paleogene of Northern Africa is not surprising given the relatively extensive Paleogene fossil record of the clade in nearby Europe and contributes to an ever more complete picture of the deep history of this diverse group of birds.

Supplementary Materials: The following are available online at http://www.mdpi.com/1424-2818/12/4/163/s1: Data Files S1: raw osteological measurement data

Author Contributions: Conceptualization, N.A.S. and T.A.S.; methodology, N.A.S., T.A.S., and J.S.M.; investigation, N.A.S., T.A.S., and J.S.M.; writing-original draft preparation, N.A.S., T.A.S., and J.S.M.; writing-review and editing, N.A.S., J.S.M., and T.A.S.; visualization, N.A.S., T.A.S., and J.S.M. All authors have read and agreed to the published version of the manuscript.

Funding: NAS was supported by a National Evolutionary Synthesis Center Postdoctoral Fellowship (NESCent; NSF EF-0905606), a J.C. Meeker Postdoctoral Fellowship at the Field Museum and the Paul and Judy Benson Endowment through the Campbell Geology Museum at Clemson University. TAS is supported by the National Natural Science Foundation of China (NSFC41772013).

Acknowledgments: We thank the late G. Gunnell and C. Riddle at DPC, J. Gerwin and B. O'Shea at NCSM, B. Marks at FMNH, and C. Angle, M. Florence, H. James and C. Milensky at USNM for access to collections, G. Gunnell, E. Miller, L. Roth, N. Zelenkov, and C.D. Francis for general discussion on Paleogene avian taxonomy, N. Zelenkov for photos of S. henrici, and P. Holroyd for assistance with Fayum mammalian biogeography. This is Duke Lemur Center Publication \#1454.

Conflicts of Interest: The authors declare no conflict of interest. The funders had no role in the design of the study; in the collection, analyses, or interpretation of data; in the writing of the manuscript, or in the decision to publish the results.

\section{References}

1. Barn-Owls to Hummingbirds; Del Hoyo, J.; Elliott, A.; Sargatal, J. (Eds.) Handbook of the Birds of the World; Lynx Edicions: Barcelona, Spain, 1999; Volume 5, p. 759.

2. Kurochkin, E.N.; Dyke, G.J. The First Fossil Owls (Aves: Strigiformes) from the Paleogene of Asia and a Review of the Fossil Record of Strigiformes. Paleontol. J. 2011, 45, 445-458. [CrossRef]

3. Mayr, G. Avian Evolution: The Fossil Record of Birds and its Paleobiological Significance; Wiley Blackwell: Chichester, UK, 2017; p. 312.

4. Mayr, G. Paleogene Fossil Birds; Springer: Berlin, Germany, 2009; p. 262.

5. Chiappe, L.M. Fossil Birds from the Miocene Pinturas Formation of Southern Argentina. J. Vertebr. Paleontol. 1991, 11, 21-22. 
6. Pavia, M.; Manegold, A.; Haarhoff, P. New Early Pliocene Owls from Langebaanweg, South Africa, With First Evidence of Athene South of the Sahara and a New Species of Tyto. Acta Palaeontol. Pol. 2014, 60, 815-828.

7. Walker, C.A.; Dyke, G.J. New Records of Fossil Birds of Prey from the Miocene of Kenya. Hist. Biol. 2006, 18, 95-98. [CrossRef]

8. Milne-Edwards, A. Recherches Sur La Faune Ancienne Des Iles Mascareignes. Ann. Sci. Nat. 1873, 2, 1-1931.

9. Newton, E.; Gadow, H. On Additional Bones of the Dodo and Other Extinct Birds of Mauritius Obtained by Mr. Theodore Sauzier. Trans. Zool. Soc. Lond. 1893, 13, 281-302. [CrossRef]

10. Rich, P.V. Preliminary Report on the Fossil Avian Remains from Late Tertiary Sediments at Langebaanweg (Cape Province), South Africa. S. Afr. J. Sci. 1980, 76, 166-170.

11. Brodkorb, P. Fossil Owls from Early Man Sites of Olduvai Gorge, Tanzania. Ostrich 1984, 54, 17-27. [CrossRef]

12. Cowles, G.S. A New Genus, Three New Species and Two New Records of Extinct Holocene Birds from Réunion Island, Indian Ocean. Geobios 1993, 27, 87-93. [CrossRef]

13. Mourer-Chauvire, C.; Bour, R.; Moutou, F.; Ribes, S. Mascarenotus nov. gen. (Aves: Strigiformes), Extinct Endemic Genus from the Mascarene Islands, and M. Grucheti n. sp., Extinct Species De La Reunion. Comptes Rendus De L'académie Des Science De Paris (Iia) 1994, 318, 1699-1706.

14. Mourer-Chauviré, C.; Geraads, D. The Upper Pliocene Avifauna of Ahl Al Oughlam, Morocco: Systematics and Biogeography. Rec. Aust. Mus. 2010, 62, 157-184. [CrossRef]

15. Brunet, J. Oiseaux. Le gisement de Vertébrés Miocènes de Beni Mellal (Maroc). Notes Et Mémoires Du Service Géologique (Maroc) 1961, 155, 105-108.

16. Brunet, J. Oiseaux Miocènes De Beni Mellal (Maroc); Un Complément À Leur Étude. Notes Et Mémoires Du Service Géologique Du Maroc 1971, 237, 109-111.

17. Stewart, J.R. The Evidence for the Timing of Speciation of Modern Continental Birds and the Taxonomic Ambiguity of the Quaternary Fossil Record. In Proceedings of the 5th Symposium of the Society of Avian Paleontology and Evolution, Beijing, China, 1-4 June 2000; pp. 261-282.

18. Stewart, J.R.; Beech, M. The Miocene Birds of Abu Dhabi (United Arab Emirates) With a Discussion of the Age of Modern Species and Genera. Hist. Biol. 2006, 18, 107-117. [CrossRef]

19. Pavia, M.; Mourer-Chauviré, C. Redescription of Tyto sanctialbani Lydekker, 1893 (Aves, Strigiformes), from Its Type Locality of La Grive-Saint-alban (Middle Miocene, France). J. Vertebr. Paleontol. 2011, 31, 1093-1101. [CrossRef]

20. Roberts, D.L.; Matthews, T.; Herries, A.I.R.; Boulter, C.; Scott, L.; Dondo, C.; Mtembi, P.; Browning, C.; Smith, R.M.H.; Haarhoff, P.; et al. Regional and Global Context of the Late Cenozoic Langebaanweg (Lbw) Palaeontological Site: West Coast of South Africa. Earth-Sci. Rev. 2011, 106, 191-214. [CrossRef]

21. Baumel, J.; Witmer, L.; Baumel, J.J.; King, A.S.; Breazile, J.E.; Evans, H.E.; VandenBerge, J.C. (Eds.) Handbook of Avian Anatomy: Nomina Anatomica Avium; Nuttall Ornithological Club, 23: Cambridge, MA, USA, 1993; pp. 45-132.

22. Von Den Driesch, A. A Guide to the Measurement of Animal Bones from Archaeological Sites. Peabody Mus. Bull. 1976, 1, 103-129.

23. International Committee on Stratigraphy. International Chronostratigraphic Chart. 2017. Available online: https://www.iugs.org/ics (accessed on 13 February 2019).

24. Linnaeus, C.V. Systema Naturae Per Regna Tria Naturae, Secundum Classes, Ordines, Genera, Species, Cum Characteribus, Differtiis, Synonymis, Locis. Ed. DecimaReformata 1758, 1-4, 824.

25. Wagler, J.G. Natürliches System Der Amphibien Mit Vorangehender Classification Der Saügthiere Und Vögel: Ein Beitrag Zur Vergleichemden Zoologie. Cotta 1830, 1, 354.

26. Mourer-Chauvire, C. Les Strigiformes (Aves) Des Phosphorites Du Quercy (France): Systématique, Biostratigraphie Et Paléobiogéographie. Documents Des Laboratoires De Géologie De Lyon 1987, 99, 89-127.

27. Rasmussen, D.T.; Olson, S.L.; Simons, E.L. Fossil Birds from the Oligocene Jebel Qatrani Formation, Fayum Province, Egypt. Smithson. Contrib. Paleobiol. 1987, 61, 1-20. [CrossRef]

28. Bown, T.M.; Kraus, M.J. Geology and Paleoenvironment of the Oligocene Jebel Qatrani Formation and Adjacent Rocks, Fayum Depression, Egypt. U. S. Geol. Surv. Prof. Pap. 1987, 1452, 1-60.

29. Seiffert, E.R. Revised Age Estimates for the Later Paleogene Mammal Faunas of Egypt and Oman. Proc. Natl. Acad. Sci. USA 2006, 103, 5000-5005. [CrossRef] [PubMed]

30. Said, E.R. Cenozoic. In The Geology of Egypt; Said, R., Ed.; AA Balkema: Brookfield, WA, USA, 1990; pp. 451-486. 
31. Chapman, W.L., Jr. Appearance of Ossification Centers and Epiphysial Closures as Determined by Radiographic Techniques. J. Am. Vet. Med Assoc. 1965, 147, 138.

32. Watanabe, J.; Matsuoka, H. Ontogenetic Change of Morphology and Surface Texture of Long Bones in the Gray [sic] Heron (Ardea cinerea, Ardeidae). In Paleornithological Research; Goelich, U., Kroh, A., Eds.; Verlag Naturhistorisches Museum Wien: Wein, Austria, 2013; pp. 279-306.

33. Fowler, D.W.; Freeedman, E.A.; Scannella, J.B. Predatory Functional Morphologyin Raptors: Interdigital Variation in Talon Size is related to Prey Restraint and Immobilisation Technique. PLoS ONE 2009, 4, e7999. [CrossRef]

34. Mayr, G.; Clarke, J.A. The Deep Divergences of Neornithine Birds: A Phylogenetic Analysis of Morphological Characters. Cladistics 2003, 19, 527-553. [CrossRef]

35. Stidham, T.A.; Smith, N.A. An Ameghinornithid-Like Bird (Aves, Cariame, ?Ameghinornithidae) from the Early Oligocene of Egypt. Palaeontol. Electron. 2015, 18, 1-8.

36. Mayr, G. A Small Loon and a Large Species of Owl from the Rupelian of Belgium (Aves, Gaviiformes, Strigiformes). Palaontol. Z. 2009, 83, 247-254. [CrossRef]

37. Rich, P.V.; Bohaska, D.J. The world's oldest owl: A new strigiform from the Paleocene of southwestern Colorado. In Smithsonian Contributions to Paleobiology; Olson, S.L., Ed.; Smithsonian Institution: Washington DC, USA, 1976; Volume 27, pp. 87-93.

38. Pavia, M. A new large barn owl (Aves, Strigiformes, Tytonidae) from the Middle Pleistocene of Sicily, Italy, and its taphonomical significance. Geobios 2004, 37, 631-641. [CrossRef]

39. Miller, E.R.; Rasmussen, D.T.; Simons, E.L. Fossil Storks (Ciconiidae) From the Late Eocene and Early Miocene of Egypt. Ostrich 1997, 68, 23-26. [CrossRef]

40. Smith, N.A. Avian Fossils from the Early Miocene Moghra Formation of Egypt. Ostrich 2013, 84, 181-189. [CrossRef]

41. Dyke, G.J.; Walker, C.A. New Records of Fossil ‘Waterbirds' From the Miocene of Kenya. Am. Mus. Novit. 2008, 3610, 1-10. [CrossRef]

42. Olson, S.L.; Rasmussen, D.T. Paleoenvironment of the Earliest Hominids: New Evidence from the Oligocene Avifauna of Egypt. Science 1986, 233, 1202-1204. [CrossRef]

43. Dunning, J.B.J. CRC Handbook of Avian Body Masses, 2nd ed.; CRC press: Boca Raton, FL, USA, 2008 ; p. 655.

44. Louchart, A. Integrating the Fossil Record in the Study of Insular Body Size Evolution: Example of Owls (Aves, Strigiformes). In Proceedings of the International Symposium "Insular Vertebrate Evolution: The Palaeontological Approach", Mallorca, Spain, 16-19 September 2005; Monografies de la Societat d'Història de las Balears. Fundación Dialnet: Logroño, Spain, 2005; Volume 12, pp. 155-174.

45. Gunnell, G.F.; Miller, E.R. Origin of Anthropoidea: Dental Evidence and Recognition of Early Anthropoids in the Fossil Record, With Comments on the Asian Anthropoid Radiation. Am. J. Phys. Anthropol. 2001, 114, 177-191. [CrossRef]

46. Perry, J.M.G.; Cooke, S.B.; Runestead-Connour, J.A.; Burgess, M.L.; Ruff, C.B. Articular Scaling and Body Mass Estimation in Platyrrhines and Catyrrhines: Modern Variation and Application to Fossil Anthropoids. J. Hum. Evol. 2018, 115, 20-35. [CrossRef] [PubMed]

47. Sanders, W.J.; Trapani, J.; Mitani, J.C. Taphonomic Aspects of Crowned Hawk-Eagle Predation on Monkeys. J. Hum. Evol. 2003, 44, 87-105. [CrossRef]

48. Terry, R.C. Quantifying the Digestive Fingerprints of Predators on the Bones of Their Prey Using Scanning Electron Microscopy. Palaios 2018, 33, 487-497. [CrossRef]

49. Berger, L.R.; Clarke, R.J. Eagle Involvement in Accumulation of the Taung Child Fauna. J. Hum. Evol. 1995, 29, 275-299. [CrossRef]

50. Jarvis, E.D.; Mirarab, S.; Aberer, A.J.; Li, B.; Houde, P.; Li, C.; Ho, S.Y.W.; Faircloth, B.C.; Nabholz, B.; Howard, J.T. Whole-Genome Analyses Resolve Early Branches in the Tree of Life of Modern Birds. Science 2014, 346, 1320-1331. [CrossRef]

51. Prum, R.O.; Berv, J.S.; Dornburg, A.; Field, D.J.; Townsend, J.P.; Lemmon, E.M.; Lemmon, A.R. A Comprehensive Phylogeny of Birds (Aves) Using Targeted Next-Generation DNA Sequencing. Nature 2015, 526, 569-573. [CrossRef]

52. Ksepka, D.T.; Clarke, J.A. Affinities of Palaeospiza Bella and the Phylogeny and Biogeography of Mousebirds (Coliiformes). Auk 2009, 126, 245-259. [CrossRef] 
53. Smith, K.T.; Bhullar, B.S.; Holroyd, P.A. Earliest African Record of the Varanus Stem-Clade (Squamata: Varanidae) From the Early Oligocene of Egypt. J. Vertebr. Paleontol. 2008, 28, 909-913. [CrossRef]

54. Holroyd, P.A.; Parham, J.F. The Antiquity of African Tortoises. J. Vertebr. Paleontol. 2003, 23, 688-690. [CrossRef]

55. Grohé, C.; Morlo, M.; Chaimanee, Y.; Blondel, C.; Coster, P.; Valentin, X.; Salem, M.; Bilal, A.A.; Jaeger, J.J.; Brunet, M. New Apterodontinae (Hyaenodontida) From the Eocene Locality of Dur At-Talah (Libya): Systematic, Paleoecological and Phylogenetical Implications. PLoS ONE 2012, 7, e49054. [CrossRef]

56. Holroyd, P.A.; Maas, M.C. Anthropoid Origins; Fleagle, J.G., Kay, R.F., Eds.; Plenum Press: New York, NY, USA, 1994; pp. 297-334.

57. De Pietri, V.L.; Mourer-Chauvire, C.; Menkveld-Gfeller, U.; Meyer, C.A.; Costeur, L. An Assessment of the Cenozoic Avifauna of Switzerland, With a Description of Two Fossil Owls (Aves, Strigiformes). Swiss J. Geosci. 2013, 106, 187-197. [CrossRef]

58. Mayr, G.; De Pietri, V.L.; Scofield, R.P.; Smith, T. A Fossil Heron from the Early Oligocene of Belgium: The Earliest Temporally Well-Constrained Record of the Ardeidae. IBIS 2017, 161, 79-90. [CrossRef]

59. Stidham, T.A.; Wang, Y.Q. An Ameghinornithid-Like Bird (Aves: Cariamae: Ameghinornithidae?) From the Middle Eocene of Nei Mongol, China. Vertebr. Palasiat. 2017, 55, 218-226.

60. Zelenkov, N.V.; Panteleyev, A.V. A Small Stem-Galliform Bird (Aves: Parortygidae) From the Eocene of Uzbekistan. Comptes Rendus Paleovol 2019, 18, 517-523. [CrossRef]

61. Liu, Z.; Pagani, M.; Zinniker, D.; Deconto, R.; Huber, M.; Brinkhuis, H.; Shah, S.R.; Leckie, R.M.; Pearson, A. Global Cooling During the Eocene-Oligocene Climate Transition. Science 2009, 323, 1187. [CrossRef]

62. Vantuinen, M.; Stidham, T.A.; Hadly, E.A. Tempo and Mode of Modern Bird Evolution Observed with Large-Scale Taxonomic Sampling. Hist. Biol. 2006, 18, 205-221.

63. Brown, J.W.; Payne, R.B.; Mindell, D.P. Nuclear DNA Does Not Reconcile 'Rocks' and 'Clocks' in Neoaves: A Comment on Ericson Et Al. Biol. Lett. 2007, 3, 257-260. [CrossRef] [PubMed]

64. Palmqvist, P.; Vizcaíno, S.F. Ecological and Reproductive Constraints of Body Size in the Gigantic Argentavis Magnificens (Aves, Theratornithidae [Sic]) From the Miocene of Argentina. Ameghiniana 2003, 40, 379-385.

65. Fox-Dobbs, K.; Stidham, T.A.; Bowen, G.J.; Emslie, S.D.; Koch, P.L. Dietary Controls on Extinction Versus Survival Among Avian Megafauna in the Late Pleistocene. Geology 2006, 34, 685-688. [CrossRef]

66. Facenna, C.; Glisovic, P.; Forte, A.; Becker, T.W.; Garzanti, E.; Sembroni, A.; Gvirtzman, Z. Role of Dynamic Topography in Sustaining the Nile River Over 30 Million Years. Nat. Geosci. 2019, 12, 1012-1017. [CrossRef] 